\title{
Miocene sepiids (Cephalopoda, Coleoidea) from Australia
}

\author{
Martin Košt’ák ${ }^{1}$, Andrej Ruman ${ }^{2}$, Ján Schlögl ${ }^{2}$, Natalia Hudáčková ${ }^{2}$, Dirk Fuchs ${ }^{3}$, and Martin Mazuch ${ }^{1}$ \\ ${ }^{1}$ Institute of Geology and Palaeontology, Faculty of Science, Charles University in Prague, Albertov 6, Prague 2, \\ 128 43, Czech Republic \\ ${ }^{2}$ Department of Geology and Paleontology, Faculty of Natural Sciences, Comenius University, Mlynská dolina, Ilkovičova 6, \\ 84215 Bratislava, Slovakia \\ ${ }^{3}$ Earth and Planetary System Science, Department of Natural History Sciences, Hokkaido University, Sapporo, Japan
}

Correspondence to: Martin Košt’ák (martin.kostak@natur.cuni.cz)

Received: 6 February 2017 - Revised: 3 April 2017 - Accepted: 4 April 2017 - Published: 25 April 2017

\begin{abstract}
Two sepiid genera, Notosepia Chapman, 1915, and Sepia Linnaeus, 1758, are described from the Neogene deposits of Australia. A new and unique record of the middle Miocene Sepia sp. is reported from southern Australia. Based on similarities to contemporaneous sepiids, the new sepiid cuttlebone described herein belongs to the genus Sepia. Notosepia cliftonensis is suggested herein to be a descendant of the archaeosepiid stem lineage. Microstructures (lamellafibrillar nacre is the nacre Type II of septa and pillar prismatic layers) of the excellently preserved cuttlebone of Sepia sp. display a modern character of the phragmocone, fully comparable to the recent taxa. The stratigraphically wellcalibrated (based on foraminifera) cuttlebone represents the first unambiguous fossil record of the genus Sepia from the Southern Hemisphere. It significantly extends the biogeographical distribution of modern sepiids in the Miocene and suggests the existence of a sepiid eastward migratory route. Moreover, the presence of both conservative- and moderntype cuttlebones suggests a dual colonisation of Australian waters: the first (archaeosepiid) during the late Eocene-late Oligocene and the second (sepiid) during the early Miocene.
\end{abstract}

\section{Introduction}

The extant genus Sepia (and the entire family Sepiidae) is found worldwide (with the exception of North and South America) and is locally abundant and diverse, containing about 120 species (Reid et al., 2005). Evolutionary development of sepiids can be reconstructed thanks to the calcareous cuttlebone (sepion in other terminologies), although the fossil record of Sepiidae is relatively scarce. Higher abun- dances and diversities have been recorded in the Miocene from the Tethys (Mediterranean region) and the Central Paratethys (Košt'ák et al., 2016). Outside this area, only a single record from western India (Saurashtra region, Gujarat state) is documented (Mohan and Chatterji, 1956); however, these specimens were neither figured nor described (see below). A new record from Australia significantly influences our knowledge about the geographical distribution of modern cuttlefishes during the Neogene. Based on the cuttlebone described herein, it becomes clear that the genus Sepia had already reached Australia in the Miocene. Australia's shelf areas are among the biotopes with the highest actual cuttlefish diversity, counting 34 species of Sepia (including two questionable records), one Metasepia species and two Sepiella species. Northern Australia actually has a higher diversity than the southern part (23 versus 15 Sepia species). Moreover, the genera Metasepia and Sepiella are restricted to northern Australia. This is in striking contrast with a single fossil record presented herein. The highest diversity of Miocene sepiids is documented from the Mediterranean and Paratethys seas, whereas only three species inhabit the recent Mediterranean Sea (S. elegans Blainville, S. officinalis Linnaeus and $S$. orbignyana Férussac in d'Orbigny).

Precursors of the Sepiidae, the Belosaepiidae, first appeared in the Late Cretaceous (Ceratisepia Meyer, 1993) and diversified during the Palaeocene (two to three genera) and the Eocene (five genera). Belosaepiid cuttlebones mainly differ from their modern derivates by a strongly mineralised dorsal shield (composed of both calcite and aragonite), inclined septa, the absence of a fork, and the absence of pillars in the phragmocone chambers (see below). Chapman (1915) described the genus Notosepia from the Balcombian (middle 
Miocene) of Australia and he correctly separated Notosepia from Sepia, owing to belosaepiid features such as a massive shield and spine as well as widely spaced chambers. Nevertheless, the cuttlebone of Notosepia appears transitional between modern Sepia (see below) and Paleogene belosaepiids. In this respect, the mosaic character of Notosepia's morphology represents an important taxon that enhances our understanding of sepiid evolution. It is the aim of the present contribution to investigate a poorly known Neogene sepiid fauna from Australia with emphasis on systematics, stratigraphy and palaeobiogeography.

\section{Material and methods}

Five specimens of Notosepia cliftonensis Chapman, 1915, deposited in the collections of Museums Victoria in Melbourne in Australia (no. P12607, P12609, P126010, P324157, P324158), were studied. The only specimen not figured herein (no. P12608) is the counterpart of the holotype (no. P12607). Here, we refigure the type material for the first time since the original publication of Chapman in 1915. The new Miocene specimen determined as Sepia sp. is stored under item no. 28324, Tate Museum, University of Adelaide. Sepia sp. is represented by two three-dimensionally preserved fragments of the cuttlebone embedded in yellowish limestone.

The latter specimen was cleaned with a pneumatic air scribe and a residuum was used for micropalaeontological study. It was wetted with hydrogen peroxide for several days and wet sieved over $71 \mu \mathrm{m}$ and $1 \mathrm{~mm}$ screens. Foraminifera were picked and identified for the biostratigraphical analyses using a binocular stereoscopic microscope, a biological polarising microscope and a scanning electron microscope (SEM). Determination of foraminifers followed Loeblich and Tappan (1992), Holbourn et al. (2013) and Turco et al. (2011). Palaeoecological parameters of the obtained foraminiferal assemblage were evaluated based on the presence and dominance of taxa exhibiting special environmental significance (Boltovskoy, 1976; Boltovskoy and Wright, 1976; Murray, 2006).

\section{Geographical, geological and stratigraphical settings}

The new Miocene cuttlefish specimen described herein was collected from an unnamed outcrop along a road cut (Fig. 1) south of Mount Gambier (Gambier district, South Australia). The exposed bioclastic limestone, a well-sorted mediumgrained grainstone with dispersed macrofossils, represents the uppermost part of the Gambier Limestone Formation. The Gambier Limestone is a neritic (mid- to outer shelf), extratropical limestone up to $500 \mathrm{~m}$ thick, deposited in the Gambier Basin. It consists of grey to creamy bryozoan calcarenites with thin intercalations of marl and clay. The stratigraphic range is from the late Eocene to the middle Miocene based on planktonic and benthic foraminiferal assemblages ( $\mathrm{Li}$ et al., 2000). Generally it is divided into three members, the Greenways Member, the Camelback Member and the Green Point Member (White, 1996), in the stratigraphical order. Deposition of the Gambier Limestone Formation ceased due to a regional regression in the early middle Miocene (around the Langhian-Serravallian boundary; Li et al., 2000).

Biostratigraphy of the sepia-bearing outcrop is based on foraminifera (Fig. 1). The strong secondary calcification of foraminiferal tests, which cover the original ornamentation and hide the chamber organization, was a major obstacle for their determination. Calcite molds of the tests are abundant. Using an optical microscope with immersion oil allowed us to explore the inner structure of the foraminiferal tests and to identify some of the better-preserved specimens (Fig. 2). Calcification also cemented foraminiferal specimens to each other as well as to the mineral and rock clasts. In addition to foraminiferal tests, the ostracodan valves, echinoid spines, scarce fragments, and molds of gastropods and bivalves were observed.

Planktonic foraminifera rarely occurred but were obtained in the following association: Orbulina suturalis (Brönnimann), Orbulina sp., Globigerinoides trilobus (Reuss) and Globigerina sp. In the benthic foraminiferal association, the tests of the oxic, epiphytic morphogroup prevail (Cibicides, Heterolepa (Fig. 2r), Elphidium (Fig. 2np), Glabratella, Discorbis, Quinqueloculina), but the shallow infaunal morphogroup is also present (Ammonia, Notorotalia, Pararotalia; Fig. 2f-i). From the benthic foraminiferal assemblage, due to the poor preservation of the tests, only the Lobatula lobatula Walker and Jacob (Fig. 2q), Cibicides mediocris Finlay (Fig. 2s-u), Elphidium macellum (Fichtell and Moll) (Fig. 2n-o), Quinqueloculina cf. buchiana d'Orbigny (Fig. 2m), Tretomphalus bulloides (d'Orbigny) and Ammonia parkinsoniana (d'Orbigny) (Fig. 2j-1) could be determined to species level. First occurrence datum of Orbulina suturalis (Brönnimann) (Fig. 2a-e) is about 15.1 Ma (Berggren et al., 1995), which correlates well with the terminal part of the Gambier Limestone Formation (Fig. 1), just before the mentioned regional regression ( $\mathrm{Li}$ et al., 2000). Other foraminiferal species from the studied association have long stratigraphical ranges. Hence, the new specimen of Sepia sp. from Victoria coexisted with Notosepia cliftonensis.

\section{Systematic palaeontology}

The terminology of macroscopic features used herein follows previous authors (see Košt'ák et al., 2013, and the discussion therein). The microstructure terminology follows Le Pabic et al. (2016). Sepiid and belosaepiid cuttlebones and their terminology are shown in Fig. 3. 


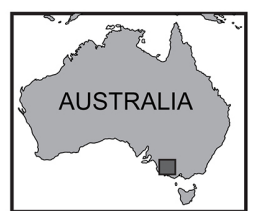

(a)

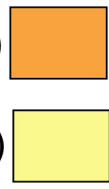

(b)
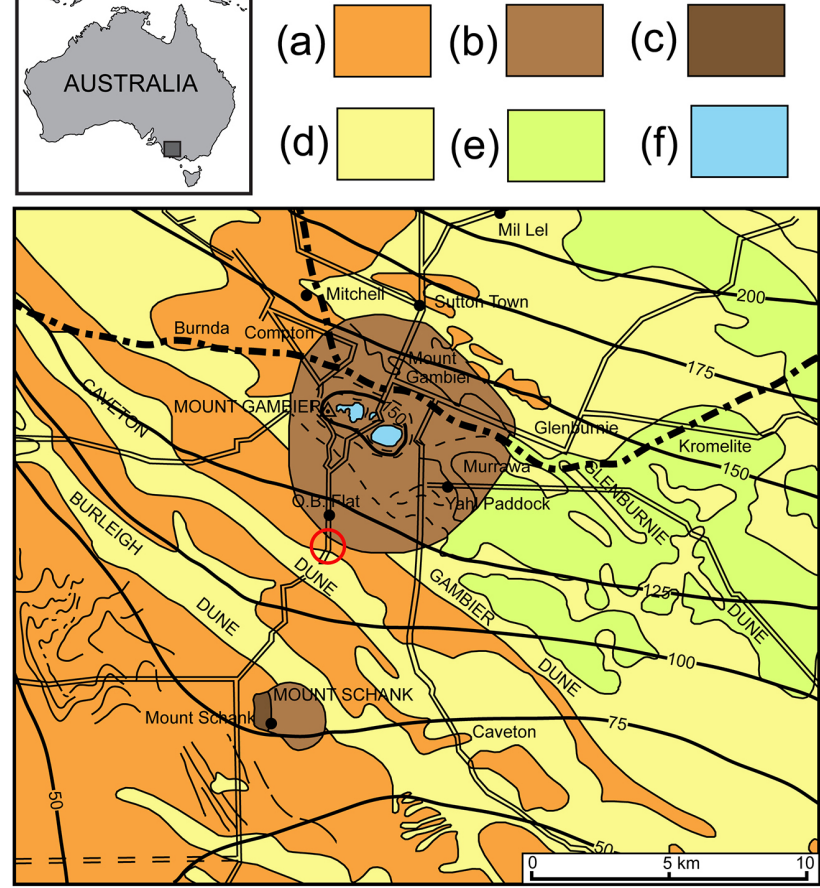

(c)

(f)
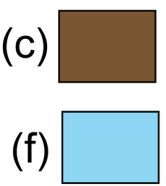

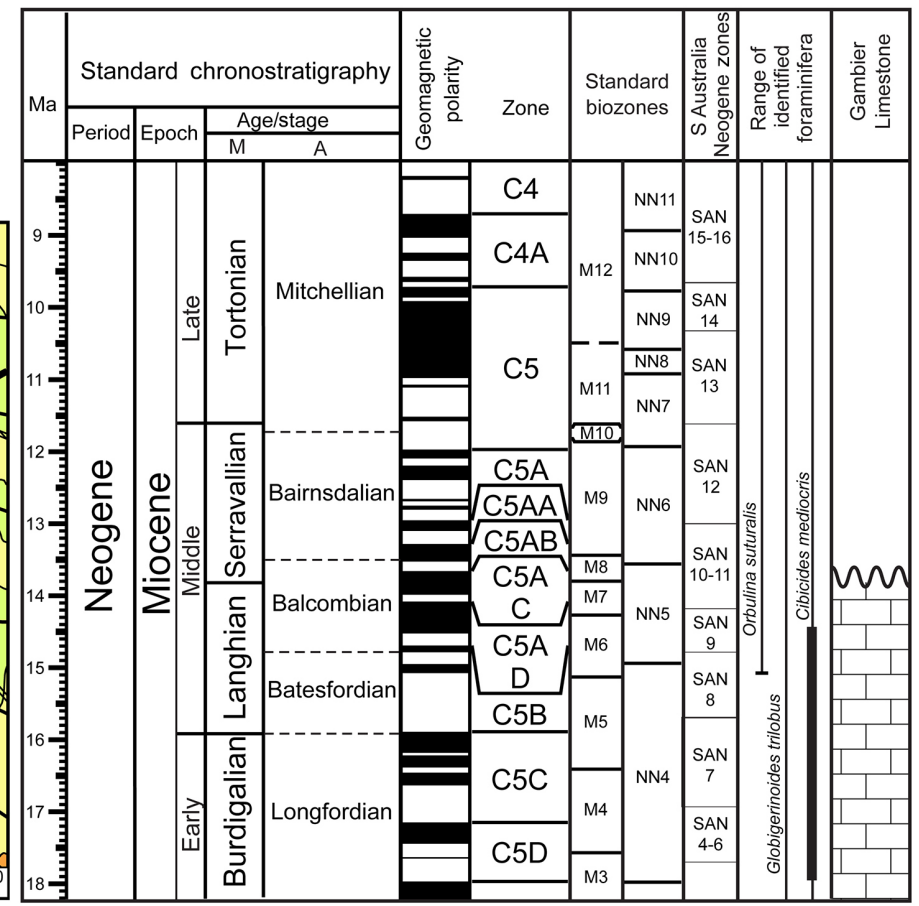

Figure 1. Detail of the geological map of the Gambier district (after Sprigg et al., 1951, slightly modified) and the stratigraphic chart of the Miocene with ranges of some of the recognised foraminifera. Legend of the geological map shows (a) Gambier Limestone, fossiliferous limestones, bryozoan limestones, marls, dolomites, flint beds (Neogene), (b) ash, lapilli, volcanic bombs (Pleistocene), (c) basalts, olivine basalts, scoria (Pleistocene), (d) aeolianite consolidated beach sands, including travertinous horizons (Pleistocene), (e) deep flat-lying sands, sand sheets, meadow podsols (recent) and (f) actual lakes. Red circle marks the outcrop area. Stratigraphic charts, zonations and their correlation are based on Berggren et al. (1995); Gradstein et al. (2012); Li et al. (2000, 2004); and Gallagher and Gourley (2007).

Subclass Coleoidea Bather, 1888

Order Sepiida Gray, 1849

(Families included Sepiidae Leach, 1817, and Belosaepiidae Dixon, 1850)

Family ?Sepiidae Leach, 1817

Genus Notosepia Chapman, 1915

Type species. Notosepia cliftonensis Chapman (1915), p. 357, pl. 7, figs. 16-17.

Diagnosis (emended herein). Dorsal shield convex; posterior shell remains massive, belosaepiid-like; ventral process short, grooved; ventral deck absent; fork present; shoulder indistinct; apical spine slender, adapically directed, apex pointed.

\section{Notosepia cliftonensis Chapman, 1915}

(Fig. 4)

Synonymy:

1915 Notosepia cliftonensis sp. nov. Chapman, p. 357, pl. 7, figs. 16-17, pl. 8, figs. 20-22.

1970 Notosepia cliftonensis. - Darragh, p. 128.

1998 Notosepia Chapman, 1915. - Riegraf et al., p. 160.
2001 Notosepia cliftonensis. - Lu, p. 131.

2016 Notosepia cliftonensis Chapman. - Košt'ák et al., p. 2.

Material. Holotype P12607 (Fig. 4a-c, see Chapman 1915: pl. 7, figs. 16-17, show posterior shell fragment) and P12608 (Chapman 1915: pl. 8, fig. 22, shows internal mould of P12607 including also anterior parts of the cuttlebone).

Paratypes P12609-10 (Fig. 4d-e, n-q, see Chapman 1915: pl. 8, figs. 20-21). Additional material available P324157-58 (Fig. 4f-m) and two unfigured specimens from the Museums Victoria collection.

Locality and age. Clifton Bank (Muddy Creek) near Hamilton, Victoria state, southeastern Australia.

Type horizon. Port Campbell Limestone (Otway Basin), Muddy Creek Marl Member, Balcombian, middle Miocene (see Fitzgerald, 2004: p. 187). According to Chapman (1915): Balcombe Bay and Grice's Creek near Melbourne (Port Phillip), Fyansford Formation, Balcombian. Victoria state. Middle Miocene, Balcombe Clay, Fyansford Formation, Muddy Creek Marl Formation. 


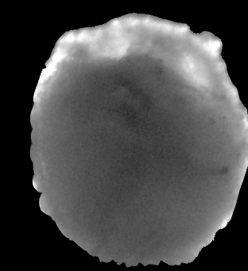

(a)

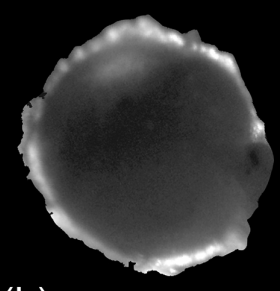

(b)

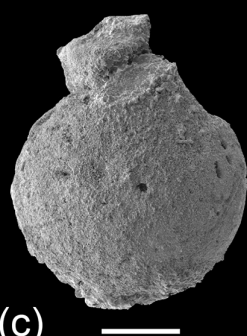

(c)

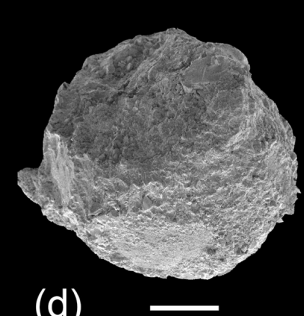

(d)

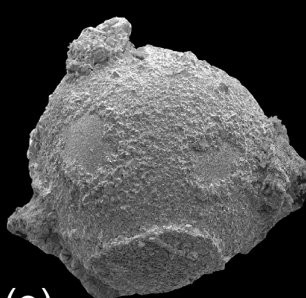

(e) (f)

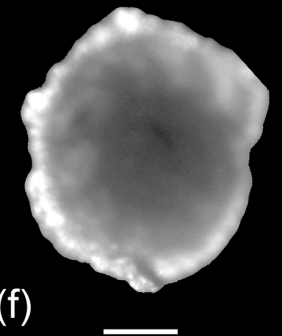

(g)
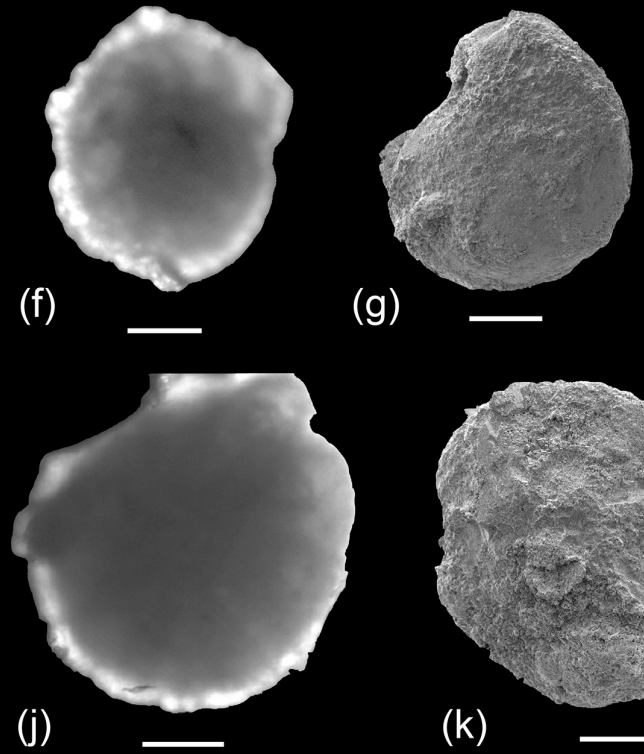

(j)

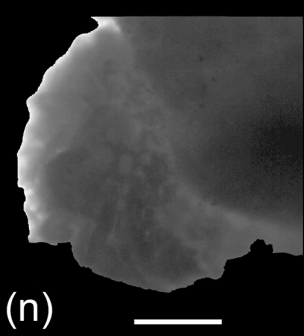

(n)

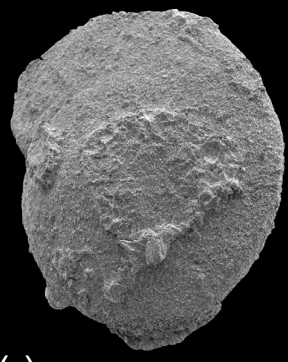

(r)

(o)

(s)

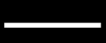

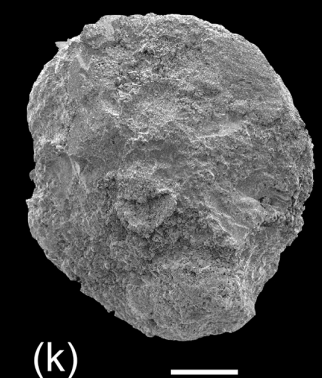

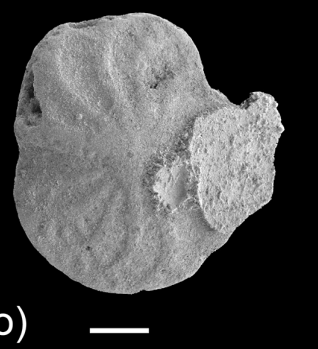

(p)

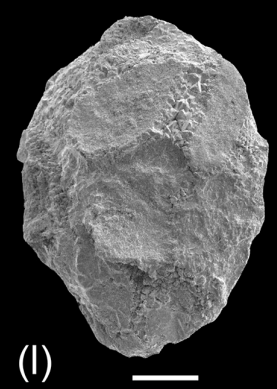

(h)

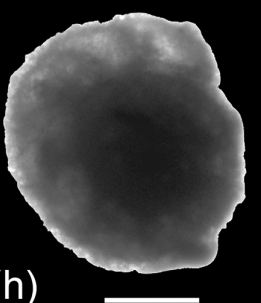

(l)

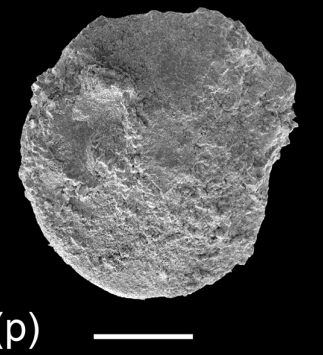

(i)

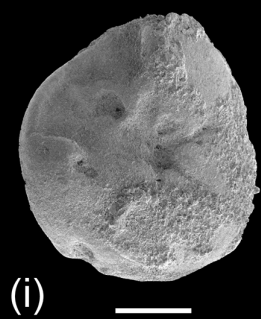

(m)
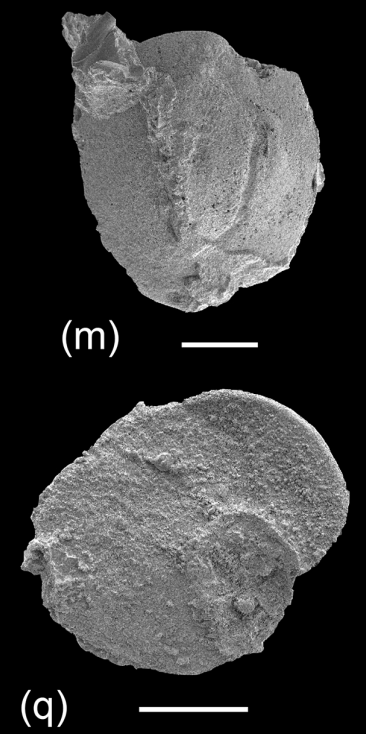

(q)

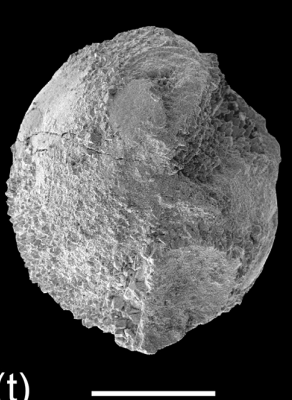

(t)

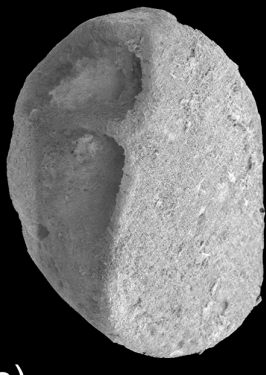

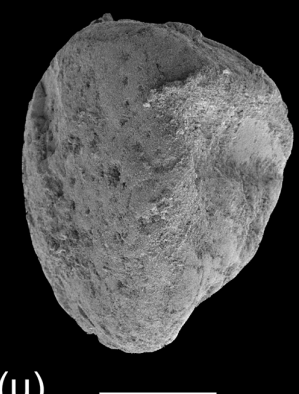

(u)

Figure 2. Foraminiferal association of the cuttlebone-bearing limestone. (a-e) Orbulina suturalis (Brönnimann); (f-i) Pararotalia sp., (f-h) spiral views, (i) umbilical view; (j-l) Ammonia parkinsoniana (d'Orbigny), (j) spiral view, (k) umbilical view, (l) side view; (m) Quinqueloculina cf. buchiana d'Orbigny; (n-o) Elphidium macellum (Fichtell \& Moll), side views; (p) Elphidium sp., side view; (q) Lobatula lobatula Walker \& Jacob, umbilical view; (r) Heterolepa sp., spiral view; (s-u) Cibicides mediocris Finlay, (s-t) side views, (u) umbilical view. Scale bar $100 \mu \mathrm{m}$ 

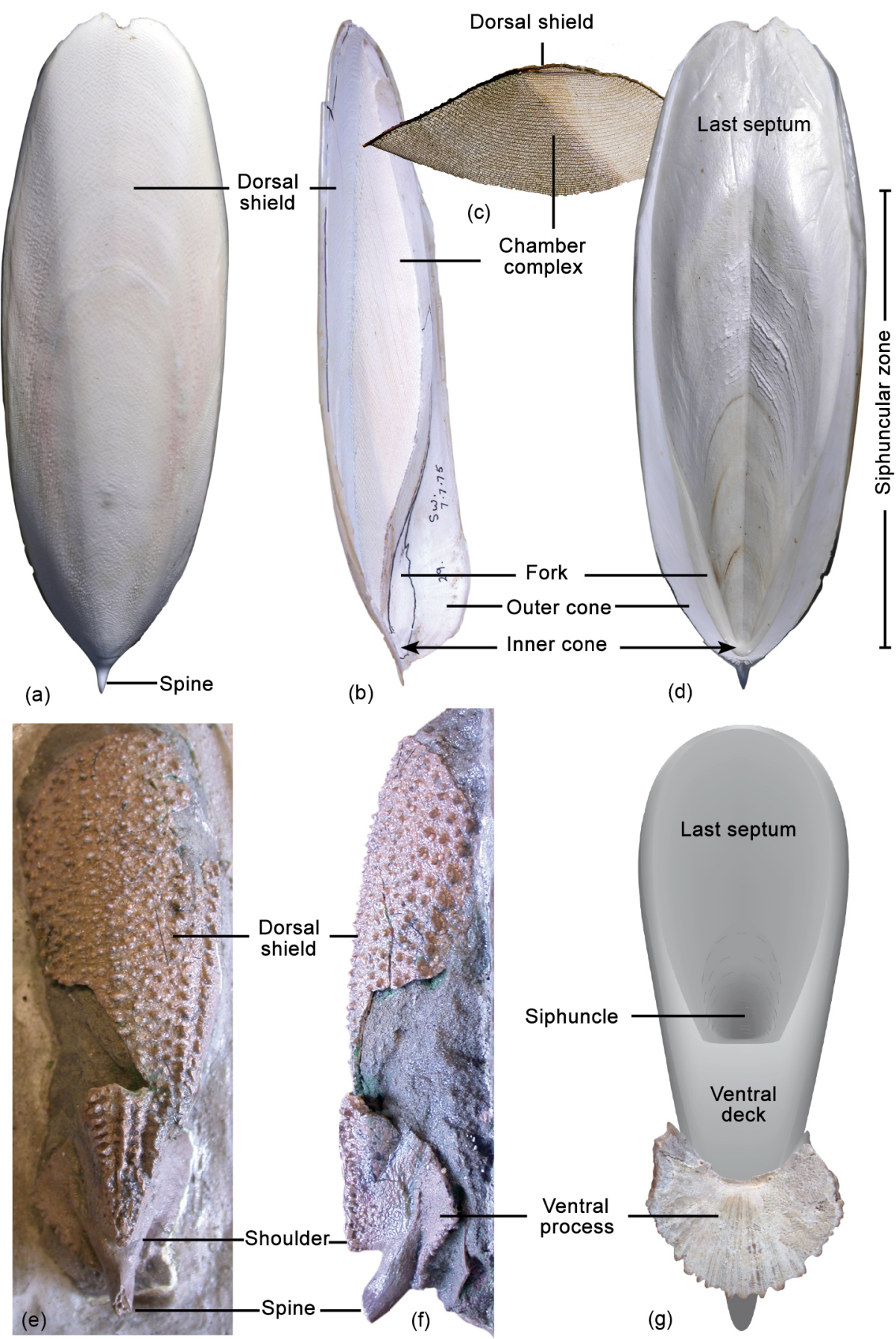

Figure 3. The extant Sepia (a-d) and extinct Belosaepia (e-g) cuttlebones with morphologic terminology. (a) Dorsal view, (b) lateral view, (c) cross section showing the chamber complex, (d) ventral view, (e) dorsal view, (f) lateral view, (g) ventral view.

Description. For a detailed description, see Chapman (1915: p. 357-358).
Discussion. Though the available cuttlebones are fragmentary and imperfectly preserved, Chapman (1915: p. 358) correctly recognised the peculiarity of Notosepia cliftonensis. The cuttlebone appears belosaepiid-like in many aspects: the dorsal shield is thick, coarsely granulated and 
strongly convex. The spine (prong in other terminologies) is massive, the shoulder is indistinct but in some specimens may be slightly indicated, and septa are oblique and widely spaced. However, in contrast to most belosaepiids, the ventral process (corona in other terminologies, Chapman's alveolar lip) is poorly developed and not flared backwards. Also, the belosaepiid ventral deck (Fig. 3) is missing. Finally and most importantly, a fork is evident, a feature that does not exist in belosaepiids and that chiefly delimits primitive (belosaepiid) and advanced (sepiid) cuttlebones.

Family Sepiidae Leach, 1817

Genus Sepia Linnaeus, 1758

Sepia sp.

(Figs. 5-8)

Material. A single rock sample comprising two cuttlebone fragments (not clear if they belong to one individual), with the larger one possessing important morphological features. Specimen stored in the Tate Museum of the University of Adelaide under item no. 28324.

Locality and age. Road cut south of Mount Gambier, Gambier district, South Australia (Fig. 1). Gambier Limestone Formation, Green Point Member. The age is restricted by the presence of Orbulina suturalis, which indicates an age younger than $15.1 \mathrm{Ma}$, and the regional regression around the Langhian-Serravallian boundary. This stratigraphic interval corresponds to the late Batesfordian-Balcombian, equivalent to the Langhian-early Serravallian on the Mediterranean scale, middle Miocene.

Description. The incomplete specimen consists of the middle part of the cuttlebone. The preserved piece $(\mathrm{L}=$ $55 \mathrm{~mm}, \mathrm{~W}=43 \mathrm{~mm}$ ) probably represents about two-fifths of the total cuttlebone length (Fig. 5a). The estimated length of $130 \mathrm{~mm}$ suggests a medium-sized cuttlebone. The broken anterior and posterior ends are 37 and $35 \mathrm{~mm}$ wide respectively. The anterior height of the cuttlebone is $9.3 \mathrm{~mm}$. Details of the cuttlebone shape remain unclear, but the posterior free rims of septa, as well as the growth lines (Fig. 5b-c), suggest a prolonged oval shape (Fig. 6). Septal suture lines are densely spaced in early ontogenetic stages and are more elliptically prolonged in later growth stages. The height of the chambers (Fig. 5b-c) in early ontogenetic stages is approximately 2 times lower than in the latest preserved chamber. Septal suture lines are fine and parabolic, prominent in particular in the median portion of the shell forming visible ribs. The space between the ribs varies between 1.3 and $1.5 \mathrm{~mm}$. The surface of the dorsal part (shield) is very faintly and irregularly granulated (Fig. 8c-d). The dorsal shield is very thin and only preserved as a relic in the mediolateral posterior part. The median field area is separated only by fine lines and carries an extremely low, barely pronounced median keel. The lateral fields are markedly splayed at anterior margins, displaying straight parallel lines. Lateral keels are not developed and false keels (sensu Košt'ák et al., 2016), formed by rows of granules, are missing. Posterior and anterior parts are not preserved. Only the anterior margin of the outer cone is apparent through a fine radial striation. Chitinous and calcareous rims are not present. Morphological features of the ventral surface of the siphuncular zone (striated zone in other terminologies), indicated only in the cross section, clearly document a very wide and shallow ventral groove (rather shallow depression) in the median part of the cuttlebone (Fig. 6).

Discussion. Notosepia cliftonensis differs from this record by having a well-developed thick dorsal shield (Fig. 4) and more widely spaced septa (see Chapman, 1915, pl. 8, figs. 20, 22). In Notosepia, the dorsal granulation is also extremely developed in the middle portion (Fig. 4), in contrast to the fine granules in Sepia sp. Other morphological characteristics such as the spine and the external ornamentation of the posterior cuttlebone part cannot be compared. Sepia sp. shows very close similarities (general shape of the cuttlebone, suture lines, ornamentation character, etc.) to the Miocene cuttlefish fauna from the Mediterranean and the Central Paratethys, clearly demonstrating affinities to the extant genus Sepia. Cuttlebone microstructures support this classification (see below).

The globally less-diversified (seven species) but locally abundant genus Sepiella Gray forms almost identical cuttlebones, with only the apical spine missing. We cannot confirm the presence or absence of the spine in the studied specimen, but rather we suggest the new record to be a representative of the genus Sepia. According to the phylogeny of Sepiidae based on molecular data (Yoshida et al., 2006), Sepiella forms a clade with Sepia taxa, suggesting that the spine was lost in different lineages (i.e. Sepiella and Metasepia Hoyle). In this respect, we consider that both mentioned genera evolved later from the genus Sepia.

\section{Structures and microstructures}

The sepiid cuttlebone basically consists of the strongly mineralised dorsal shield and the delicate chamber complex (Figs. 3c, 7-8). The chamber complex is characterised by horizontal to subhorizontal septa, vertical pillars, and horizontal and vertical pillar membranes (Fig. 7). Mineralogically, the cuttlebone is composed of calcite, aragonite and organic matter ( $\beta$-chitin linked with proteins; Le Pabic et al., 2016). Microstructures of extant and extinct sepiid cuttlebones were studied in detail by numerous authors (Bandel and Boletzky, 1979; Ward and Boletzky, 1984; Gutowska et al., 2010; Doguzhaeva and Mutvei, 2012; Doguzhaeva et al., 2014; Doguzhaeva and Dunca, 2015; Checa et al., 2015; Le Pabic et al., 2016). Doguzhaeva and Dunca (2015) summarised ultrastructural terms of the siphonal zone and subsequently introduced a new term for the contacting ridges 


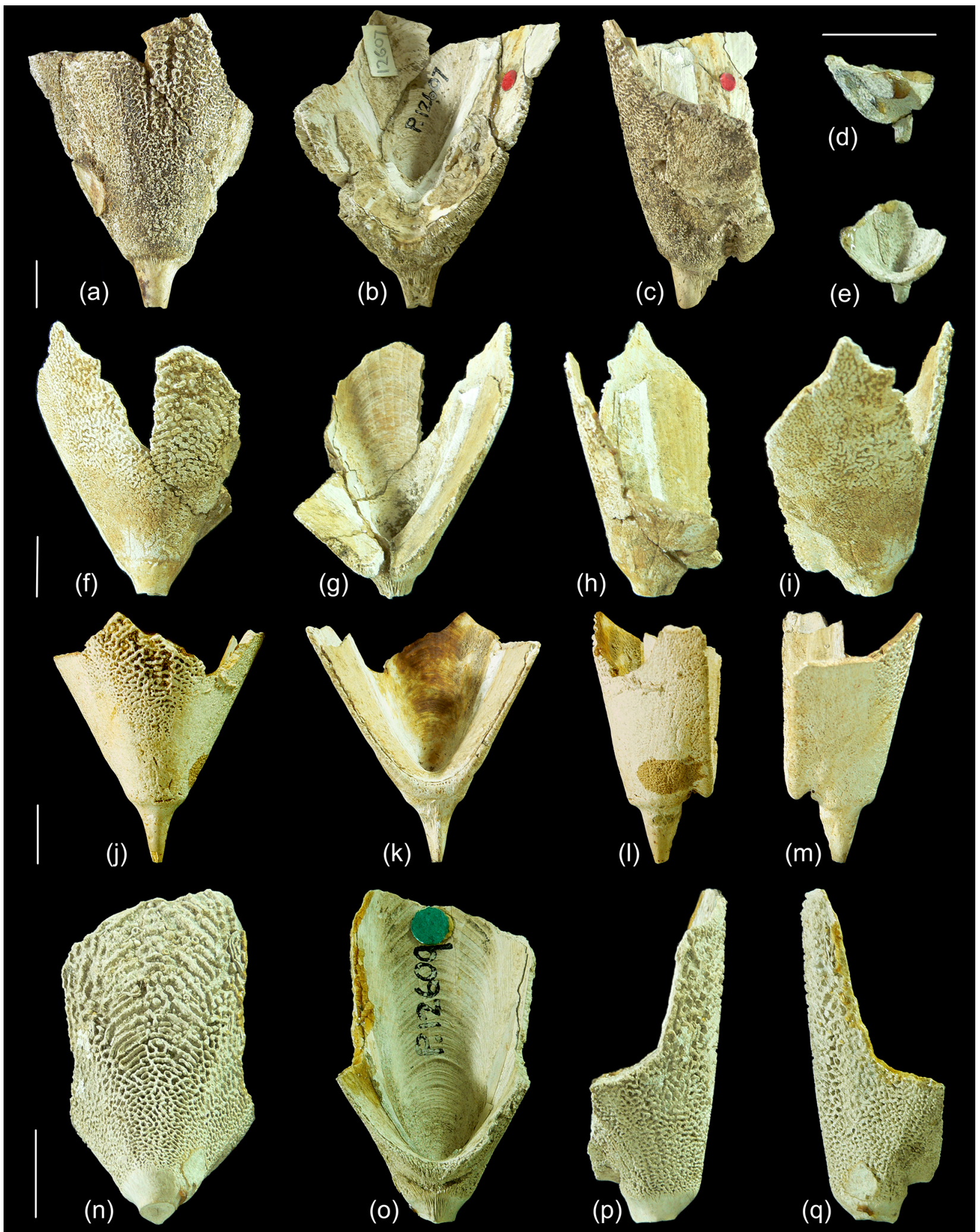

Figure 4. Notosepia cliftonensis Chapman, 1915. All specimens come from Clifton Bank near Hamilton (banks of Muddy Creek Marl Member) and are of the Balcombian age (middle Miocene). (a-c) Proximal part of the cuttlebone. Holotype, no. P12607, (a) dorsal view, (b) ventral view, (c) lateral view. (d-e) Paratype, no. P12610, (d) lateral view, (e) ventral view. (f-i) Specimen no. P324158, (f) dorsal view, (g) ventral view, (h-i) lateral views. (j-m) Specimen no. P324157, (j) dorsal view, (k) ventral view, (l-m) lateral views. (n-q) Paratype, no. 12609, (n) dorsal view, (o) ventral view, (p-q) lateral views. Scale bar $1 \mathrm{~cm}$. Photo by Rolf Schmidt (Museums Victoria). 
(a)
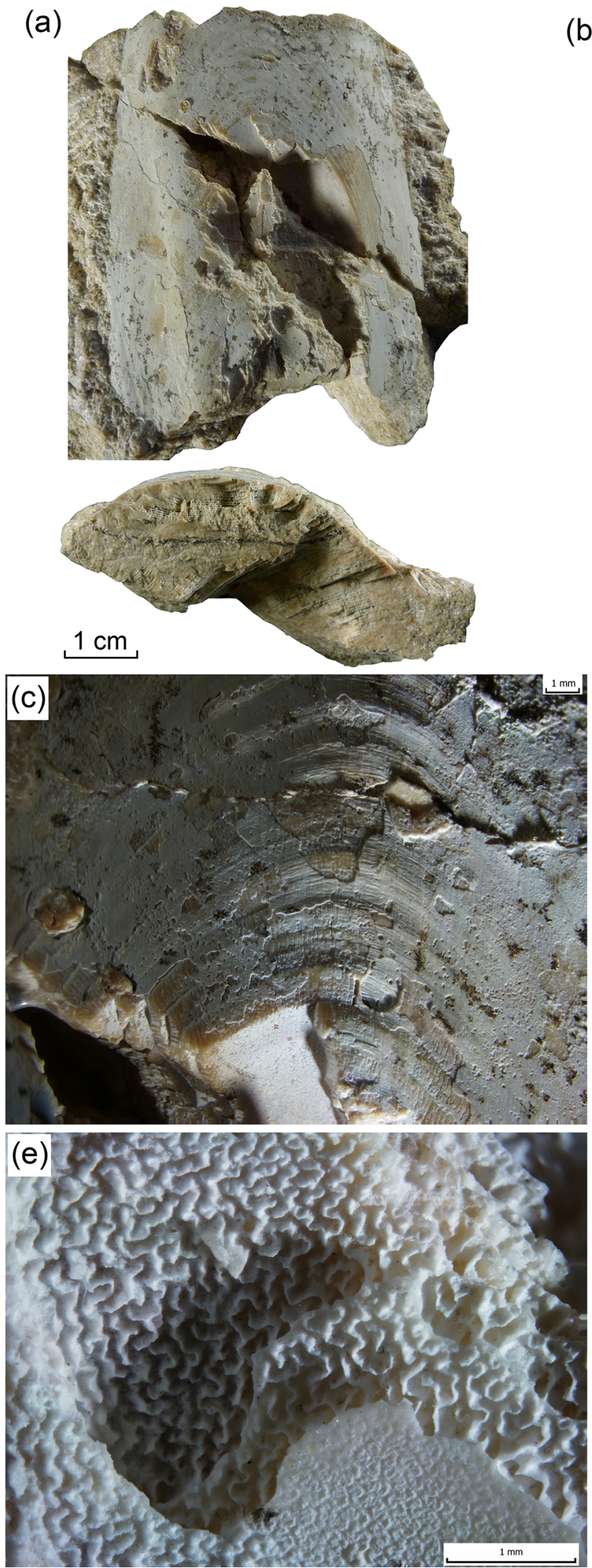

(b)
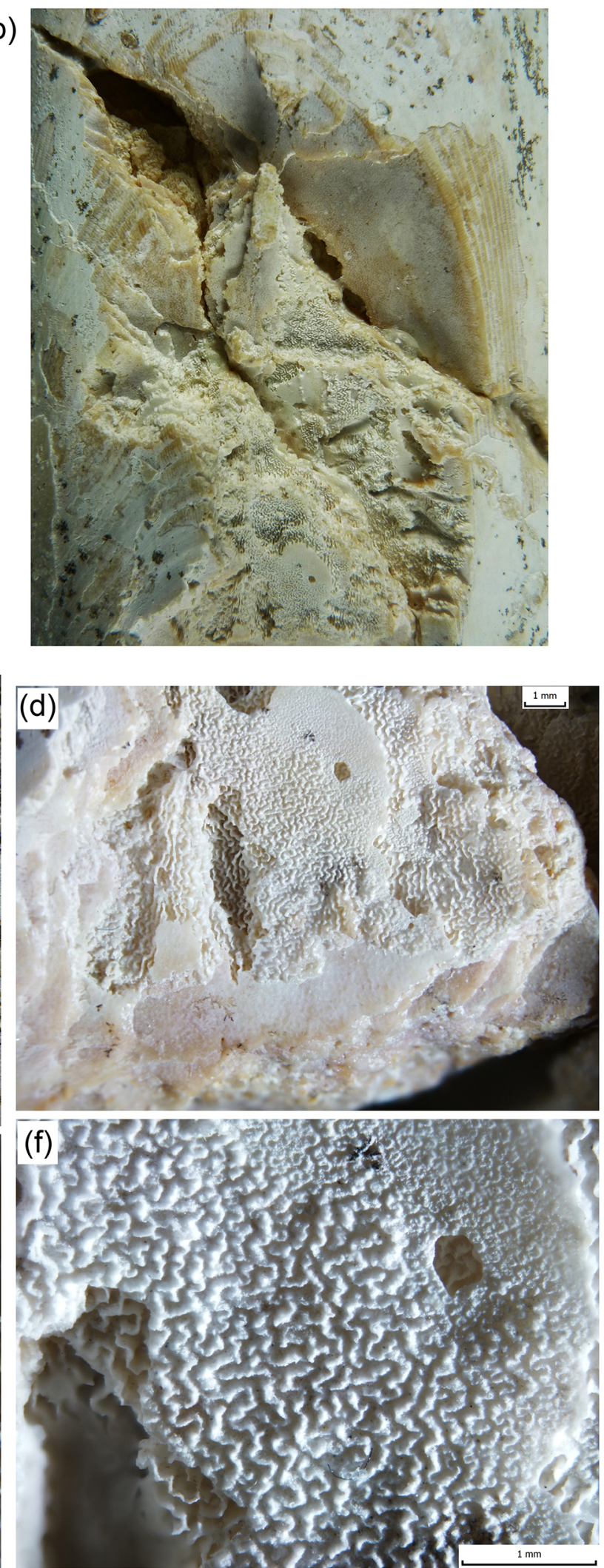

Figure 5. Sepia sp., south of Mount Gambier, Balcombian (middle Miocene). (a) Dorsal view and the cross section of the specimen. (b) Closer view of the damaged part of the dorsal part with partly unfilled chambers. (c) Detail of the cuttlebone growth lines and (d-f) pillars. 


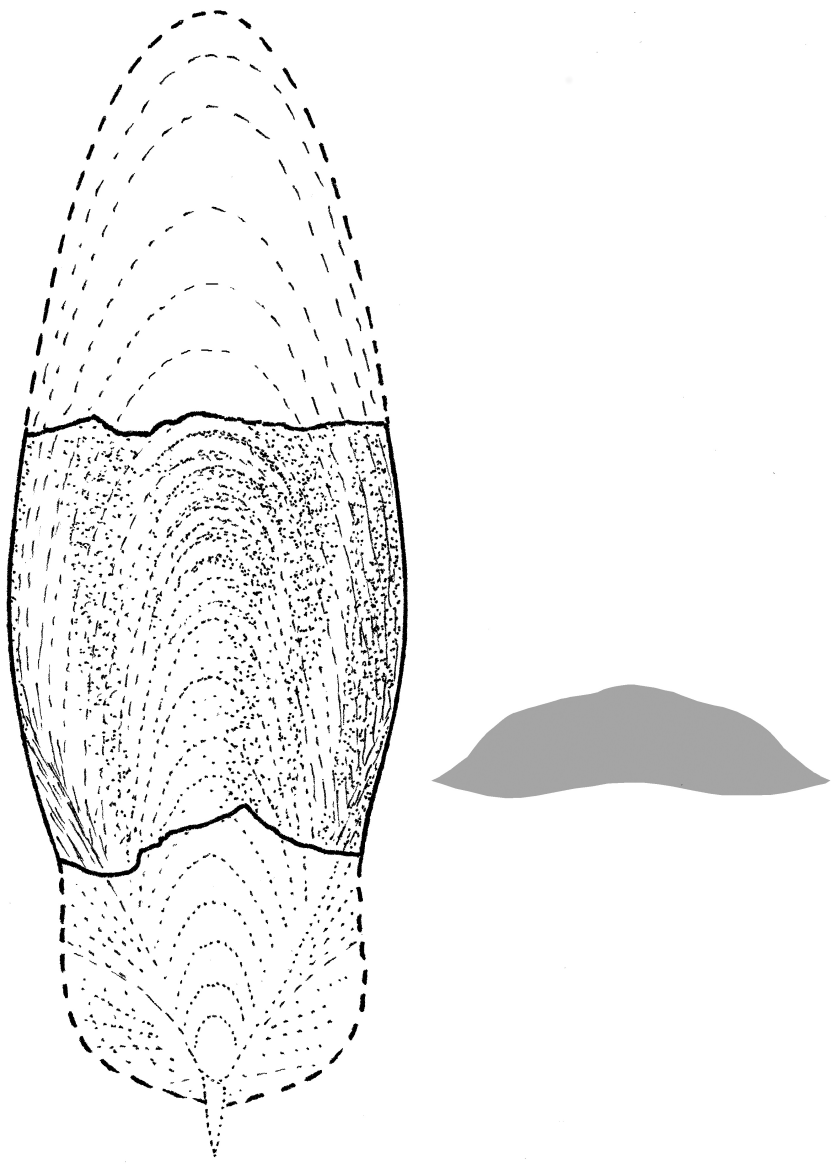

Figure 6. Position of the preserved part within the cuttlebone and the cross section (grey) showing the ventral shallow depression of the siphuncular zone.

based on well-preserved recent material. Our extraordinarily well-preserved cuttlebone from the Australian Miocene revealed surprising micro- and ultrastructural details without significant diagenetic alterations.

The dorsal shield (Fig. 8a-d), whose marginal parts are partly preserved, displays a fine granulation (Fig. 8c-d). It is formed by well-developed prismatic crystals. The septum is formed by lamella-fibrillar nacre, typical for phragmoconebearing coleoids (nacre Type II sensu Mutvei, 1970). It is characterized by microlaminated ultrastructure (Doguzhaeva and Dunca, 2015), where each lamella consists of aragonite fibres of different orientation, in some cases with visible criss-cross patterns. The most important observation concerns vertical structures, which support the horizontal septa. These structures unambiguously represent pillars (columns, undular plates or intracameral walls in other terminologies). The pillars are formed by a prismatic layer, strictly delimited from the septum proper (Fig. 8e-f). Horizontal striae along the pillars (Fig. 7a) do represent growth stages (Checa et al., 2015). The pillars are typically meandering as can be seen on weathered septal surfaces (Figs. $5 \mathrm{~d}-\mathrm{f}, 8 \mathrm{~g}-\mathrm{h}$ ).
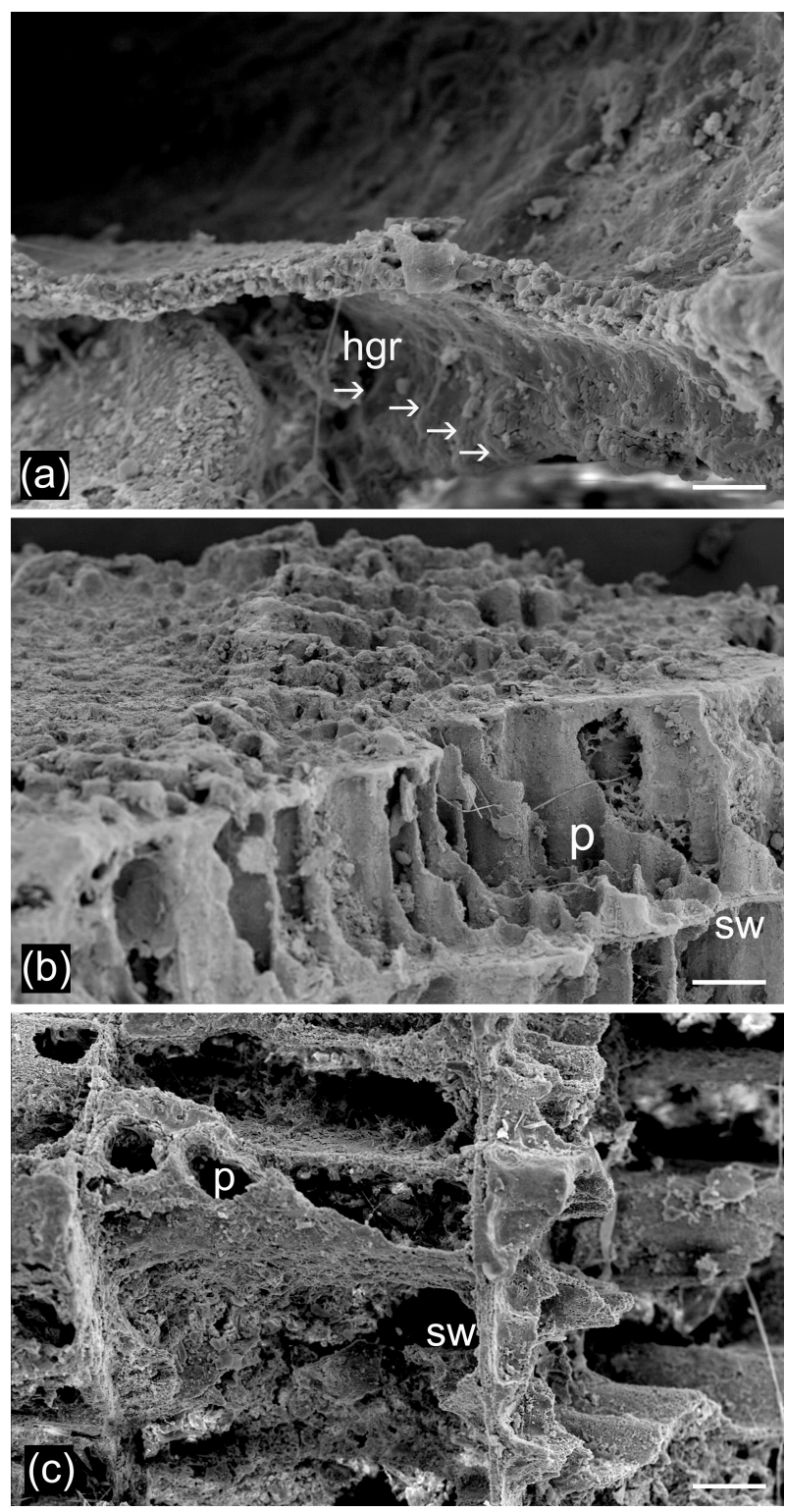

Figure 7. (a) Detail of the pillar prismatic microstructure with the horizontal regular parallel ribs (hgr) representing growth stages. (b) Chambers formed by pillars (p) intercalated by septal walls (sw) and (c) septal walls with pillar structures. Scale bars: (a) $20 \mu \mathrm{m}$, (b) $200 \mu \mathrm{m}$ and (c) $100 \mu \mathrm{m}$.

The attachment of the pillars to the preceding and succeeding septum therefore (Fig. 8h) resembles ammonoid sutures. Seilacher and Chinzei (1993, and the discussion therein) used the term pillar sutures for this ornamentation. They figured (Seilacher and Chinzei, 1993, fig. 2b-d) lineages of broken pillars (stumps), banding of pillars or pillar-elevated basis (and their drawings) but not the suture lines, which are visible in our specimen (Fig. 8g-h). Horizontally spanned organic membranes as known in a couple of extant Sepia species are not visible. 

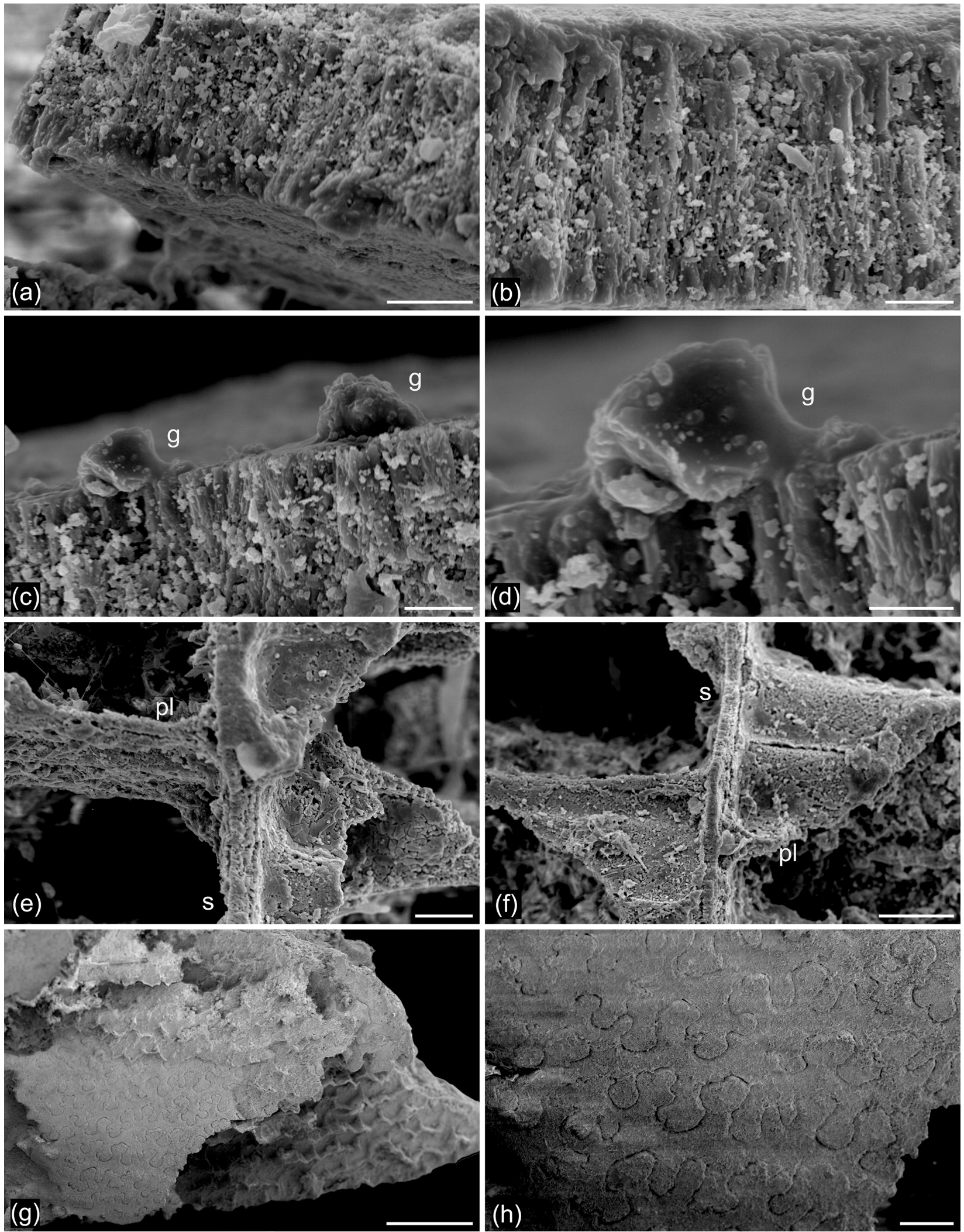

Figure 8. (a-b) Microstructures of the dorsal shield with prismatic layers, (c-d) dorsal shield with granules (g), (e-f) septal lamella-fibrillar nacre(s) and the connection with the pillar prismatic layers (pl), (g) closer view of the basis of pillars, (h) pillar sutures. Scale bars: (a) $20 \mu \mathrm{m}$, (b-c) $10 \mu \mathrm{m}$, (d) $5 \mu \mathrm{m}$, (e) $35 \mu \mathrm{m}$, (f) $65 \mu \mathrm{m}$, (g) $500 \mu \mathrm{m}$ and (h) $100 \mu \mathrm{m}$. 


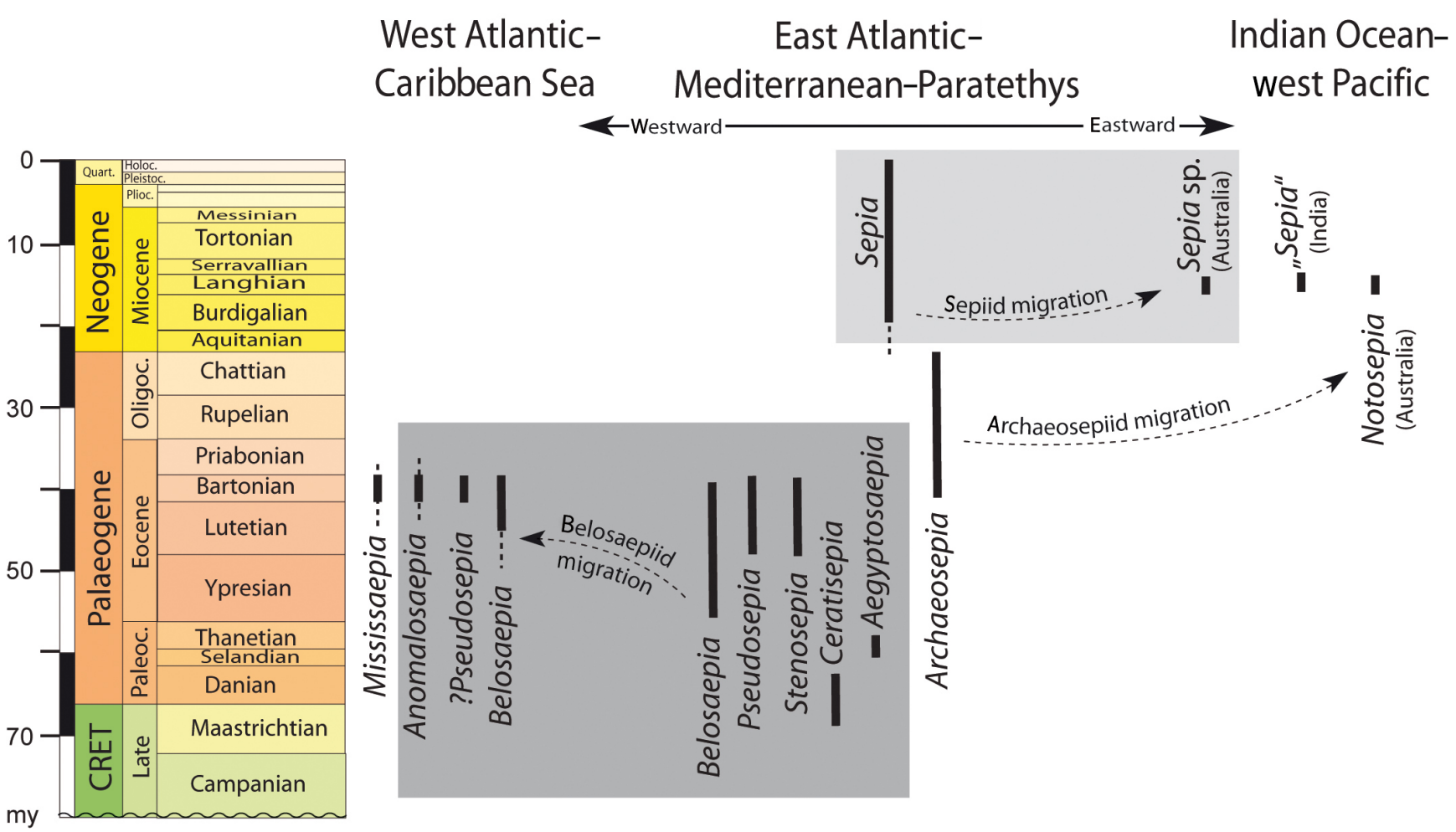

Figure 9. Stratigraphic distribution and biogeography of the Sepiida. Fork- and pillar-less Belosaepiidae (dark grey) migrated only westwards via opening Atlantic, while fork-bearing Archaeosepia and Notosepia as well as fork- and pillar-bearing Sepiidae (bright grey) migrated only eastwards.

\section{Discussion}

The record of Sepia sp. from the Miocene of Australia significantly extends the geographical distribution of the genus. The majority of fossil cuttlefish species are concentrated in the Mediterranean and the Paratethys (Košt'ák et al., 2016), while scarce records are reported from the Atlantic coast of France (Roger, 1947) and Spain (Mayoral and Muñiz, 1994). The easternmost Miocene record (before the specimen described herein) of a cuttlefish was reported from the Indian coast of Gujarat state in western India (Mohan and Chatterji, 1956); however, this material was not figured. The specimen described herein represents the first Miocene cuttlebone of modern type in the Southern Hemisphere. Thus, our record of Sepia sp. directly suggests more extensive migratory routes and subsequently clearly documents the existence of genus Sepia in the Indo-Pacific area (Fig. 9).

Chapman (1915) described the peculiar sepiid genus $\mathrm{No}$ tosepia from southern Australia (Victoria state). He correctly mentioned affinities to the extinct genus Belosaepia and analysed the differences in great detail (see Chapman, 1915, p. 358). Morphologically, Notosepia appears to be intermediate between belosaepiids and sepiids. Both belosaepiids and sepiids probably originated and radiated in the Mediterranean.
Belosaepiids migrated westwards (Košt'ák et al., 2013) and disappeared worldwide during the late Eocene: in North and South America (Weaver and Ciampaglio, 2003; Yancey et al., 2010) without descendent and in the Mediterranean with descendent, namely less-well-known sepiids like $A r$ chaeosepia Szörényi (late Eocene-late Oligocene), which are the root of advanced sepiids. Notosepia is also possibly a descendent of the Archaeosepia species group possessing a mosaic of primitive (e.g. massive spine, massive dorsal shield, wide chambers) and advanced (fork) features. This assumption implicates the development of the fork within Archaeosepia (which needs to be tested in the future). Notosepia accordingly colonised Australian waters after the decline of belosaepiids. Thus, at least three migration waves are recognisable within the order Sepiida: belosaepiid, archaeosepiid and sepiid (Fig. 9). Notosepia is seen here as a Miocene remnant of the Oligocene archaeosepiid migration, while Sepia sp. reached Australia with the Miocene sepiid eastward migration. This triple migratory hypothesis is largely congruent with Khromov (1998), who was the last one to discuss the palaeobiogeography of Sepiida. Khromov's first three (out of five) colonisation phases correspond to our belosaepiid, archaeosepiid and sepiid migrations. $\mathrm{He}$ assumed that sepiids invaded Australian waters once during the third (Miocene) phase, while we suggest a dual coloni- 
sation: archaeosepiid during the late Eocene-Oligocene and sepiid during the early Miocene.

It is notable that undamaged sepiid cuttlebones may float for a very long time - more than a year (Hewitt and Pedley, 1978) - and thus may be transported over long distances. During this period, they form a nekroplankton, commonly used by pseudoplanktonic organisms (i.e. algae, barnacles; Jongbloed et al., 2016). No signs of any organism interactions with the cuttlebone have been seen in our specimen. Therefore, we do not assume a longer post-mortem transport in the ocean. Furthermore, its exceptional state of preservation suggests the rather rapid burial of a fresh specimen.

\section{Conclusions}

A new and exceptionally well-preserved specimen (including cuttlebone microstructures) of Sepia sp. from the midMiocene of Australia documents the already wide geographical distribution of the genus in the Miocene. Before, the Miocene Sepiidae were exclusively known from the European Atlantic coast, the Mediterranean and the Central Paratethys areas. The Miocene sepiid record from western India still needs confirmation. This observation is very important for phylogeny and palaeogeography (suggesting a new sepiid eastward migratory route) as well as for the molecular analysis. The new Australian specimen from the Mount Gambier vicinity is stratigraphically calibrated based on foraminifera, indicating the late Batesfordian to Balcombian age.

Sepia sp. from southern Australia possesses all morphological features comparable to the recent genus Sepia on both macro- and microstructural levels. In these respects, we place this specimen within the genus Sepia.

The genus Notosepia described by Chapman (1915) is unique in having a mosaic of primitive and advanced features. Despite primitive belosaepiid characters, the presence of a fork led us to regard Notosepia as a descendent of the late Eocene-late Oligocene genus Archaeosepia.

Exceptionally well-preserved microstructures of the phragmocone display septal and pillar micro- and ultrastructures, including lamella-fibrillar nacre, which are typical for sepiids. Inside the microstructures observed, unusual suturelike structures (pillar sutures sensu Seilacher and Chinzei, 1993) resembling ammonite sutures occurred. Analogically, these structures may play a role in the chamber reinforcement.

Biogeographically, we can now recognize three periods of sepiid migrations: a belosaepiid during the Eocene, an archaeosepiid during the late Eocene-late Oligocene and a sepiid during the early Miocene. The presence of both a conservative (Notosepia) and a modern type (Sepia sp.) of cuttlebone suggests a dual (archaeosepiid and sepiid) colonisation of Australian waters.
Data availability. No data sets were used in this article.

Competing interests. The authors declare that they have no conflict of interest.

Acknowledgements. We are grateful to Brian McGowran (University of Adelaide) for his help with the local geological situation and Rolf Schmidt (Museum Victoria, Melbourne) for the photos of Notosepia cliftonensis. Juraj Farkaš (University of Adelaide), Petr Kraft (Faculty of Science, Charles University in Prague) and Jan Sklenár (National Museum in Prague) also helped during the preparation of the paper. The research is supported by projects PROGRES Q45, APVV 0644-10, APVV 14-0118 and VEGA $2 / 0136 / 15$. We are grateful to the reviewers René Hoffmann (Bochum, Germany) and Patricia G. Weaver (Raleigh, USA) for insightful comments on an earlier draft of the paper, which significantly raised the quality of the article. Christian Klug (Zürich, Switzerland) is gratefully acknowledged for precise editorial corrections.

Edited by: C. Klug

Reviewed by: P. Weaver and R. Hoffmann

\section{References}

Bandel, K. and Boletzky, S. v.: A comparative study of the structure, development, and morphological relationships of chambered cephalopod shells, Veliger, 21, 313-354, 1979.

Bather, F. A.: Shell-growth in Cephalopoda (Siphonopoda), Ann. Mag. Nat. Hist., 6, 298-310, 1888.

Berggren, A., Kent, D. V., Swisher III, C. C., and Aubry, M.-P.: A revised Cenozoic geochronology and chronostratigraphy, in: Geochronology Time Scales and Global Stratigraphic Correlation, edited by: Berggren, W. A., Kent, D. V., Aubry, M.-P., and Hardenbol J., SEPM Special Publication, 54, 129-212, 1995.

Boltovskoy, E.: Distribution of Recent foraminifera of the South American region, in: Foraminifera (Vol. 2), edited by: Hedley, R. H. and Adams, C. G., Academic Press, New York, 717-736, 1976.

Boltovskoy, E. and Wright, R. (Eds.): Recent Foraminifera, Junk, The Haugue, Dordrecht, 1976.

Chapman, F.: New or Little-known Victorian fossils in the national Museum. Part XXIV, Some Tertiary Cephalopoda, Proc. R. Soc. Victoria, 27, 350-360, 1915.

Checa, A. G., Cartwright, J. H. E., Sánchez-Almazo, I., Andrade, J. P., and Ruiz-Raya, F.: The cuttlefish Sepia officinalis (Sepiidae, Cephalopoda) constructs cuttlebone from a liquid-crystal precursor, Sci. Rep., 5, 11513, doi:10.1038/srep11513, 2015.

Darragh, T. A.: Cataloque of Australian Tertiary Mollusca (except chitons), Mem. Natl. Mus. Victoria, 31, 125-212, 1970.

Dixon, F.: The geology and fossils of the Tertiary and Cretaceous formations of Sussex, Longman, Brown, Green and Longmans, London, 1850.

Doguzhaeva, L. A. and Dunca, E.: Siphonal zone structure in the cuttlebone of Sepia officinalis, Swiss J. Palaeontol., 134, 167176, 2015. 
Doguzhaeva, L. A. and Mutvei, H.: Connecting stripes: an organic skeletal structure in Sepia from Red Sea, Geobios, 45, 13-17, 2012.

Doguzhaeva, L. A., Weaver, P. G., and Ciampaglio, C. N.: A unique late Eocene coleoid cephalopod Mississaepia from Mississippi, USA: new data on cuttlebone structure and their phylogenetic implications, Acta Palaeont. Pol., 59, 147-162, 2014.

Fitzgerald, E. M. G.: A review of the Tertiary fossil Cetacea (Mammalia) localities in Australia, Mem. Mus. Victoria, 61, 183-208, 2004.

Gallagher, S. J. and Gourley, T. L.: Revised Oligo-Miocene stratigraphy of the Murray Basin, southeast Australia, Austr. J. Earth Sci., 54, 837-849, 2007.

Gradstein, F. M., Ogg, J. G., Schmitz, M. D., and Ogg, G. M. (Eds.): The Geological Time Scale 2012, 2, Elsevier, Amsterdam, 2012.

Gray, J. E.: Catalogue of the Mollusca in the collection of the British Museum, Part 1, Cephalopoda Antepedia, Spottiswoodes and Shaw, London, 1849.

Gutowska, M. A., Melzner, F., Pörtner, H. O., and Meier, S.: Cuttlebone calcification increases during exposure to elevated seawater $p \mathrm{CO}_{2}$ in the cephalopod Sepia officinalis, Mar. Biol., 157, 1653-1663, 2010.

Hewitt, R. A. and Pedley, H. M.: The preservation of the shells of Sepia in the Middle Miocene of Malta, Proc. Geol. Ass., 89, $227-$ 237, 1978

Holbourn, A., Kuhnt, W., Clemens, S., C., Prell, W. L., and Andersen, N.: Middle to late Miocene stepwise climate cooling: Evidence from a high-resolution deep water isotope curve spanning 8 million years, Paleoceanography, 28, 1-12, 2013.

Jenkins, D. G.: Planktonic foraminifera from the Lakes Entrance Oil Shaft, Victoria, Australia, Micropaleontology, 6, 345-371, 1960.

Jongbloed, C. A., de Gier, W., Ruiten, D. M., van, Donovan, S. K.: Aktuo-Paläontologie of the common cuttlefish,Sepia officinalis, an endocochleate cephalopod (Mollusca) in the North Sea, Pal. Z., 90, 307-313, 2016.

Khromov, D. N.: Distribution patterns in Sepiidae, Smithsonian Contr. Zool., 568, 191-206, 1998.

Košt'ák, M., Jagt, J. W., Speijer, R. P., Stassen, P., and Steurbaut, E.: New Paleocene Sepiid Coleoids (Cephalopoda) from Egypt: Evolutionary Significance and Origin of the Sepiid 'Rostrum', PloS ONE, 8, e81180, doi:10.1371/journal.pone.0081180, 2013.

Košt'ák, M., Schlögl, J., Hudáčková, N., Kroh, A., Halásová, E., Gašparič, R., Hyžný, M., and Wanzenböck, G.: Sepia from the Miocene of the Central Paratethys: new taxa and notes on late Cenozoic cuttlefish diversity, J. Syst. Palaeontol., 14, 1033-1057, 2016.

Leach, W. E.: Synopsis of the orders, families and genera of the class Cephalopoda, The Zoological Miscellany; being descriptions of new or interesting animals, 3, 137-141, 1817.

Le Pabic, C., Rousseau, M., Bonnaud-Ponticelli, L., and Boletzky, S. v.: Overview of the shell development of the common cuttlefish Sepia officinalis during early-life stages, Vie Milieu, 66, 35-42, 2016.

Li, Q., McGowran, B., and White, M. R.: Sequences and biofacies packages in the mid-Cenozoic Gambier limestone, South Australia: reappraisal of foraminiferal evidence, Austr. J. Earth Sci., 47, 955-970, 2000.
Li, Q., Simo, J. A., McGowran, B., and Holbourn, A.: The eustatic and tectonic origin of Neogene unconformities from the Great Australian Bight, Mar. Geol., 203, 57-81, 2004.

Linnaeus, C.: Systema Naturae per regna tria naturae, secundum classes, ordines, genera, species, cum characteribus, differentiis, synonymis, locis, Editio decima, reformata, Holmiae: Laurentius Salvius, Stockholm, 1758.

Loeblich, A. R. and Tappan, H.: Present status of Foraminiferal Classification, in: Studies in Benthic Foraminifera, edited by: Takayanagi, Y. and Saito, T., Tokio University Press, 93-102, 1992.

Lu, C. C.: Cephalopoda, in: Mollusca: Aplacophora, Polyplacophora, Scaphopoda, Cephalopoda (Zoological Catalogue of Australia Series), Zoological Catalogue of Australia 17, 2, edited by: Lamprell, K. L., Healy, J. M., Scheltema, A. M., GowlettHolmes, K., and Lu, C. C., CSIRO Publishing, 131 pp., 2001.

Meyer, C.: Un nouveau coleoide sepioide Ceratisepia elongata nov. gen., nov. sp. du Paleocene inferieur (Danian) de Vigny. Implications taxonomiques et phylogenetiques. Géobios, Mémoire Special, 15, 287-304, 1993.

Mohan, K. and Chatterji, A. K.: Stratigraphy of the Miocene beds of Kathiawar, western India, Micropaleontology, 2, 349-356, 1956.

Mayoral, E. and Muñiz, F.: A new Sepioid Cephalopoda in the Upper Neogene from the Guadalquivir Basin (Lepe, Huelva, Spain), Coloquios de Paleontología, 46, 161-174, 1994.

Murray, J. W.: Ecology and Applications of Benthic Foraminifera, Cambridge University Press, New York, 2006.

Mutvei, H.: Ultrastructure of the mineral and organic components of molluscan nacreous layers, Biomineralization, 2, 48-72, 1970.

Reid, A., Jereb, P., and Roper, C. F. E.: Cuttlefishes, in: Cephalopods of the world. An Annotated and Illustrated catalogue of Cephalopod species known to date, FAO Species Catalogue for Fishery Purposes, 4 (1), edited by: Jereb, P. and Roper C. F. E., Food and Agriculture Organization of the United Nations, Rome, 56-179, 2005.

Riegraf, W., Janssen, N., and Schmitt-Riegraf, C.: A. Cephalopoda dibranchiata fossils (Coleoidea) II. in: Fossilum Catalogus I. Animalia, 135, edited by: Westphal, F., Backhuys Publishers, Leiden, 512 pp., 1998.

Roger, J.: Découverte d'une coquille de Sepia (S. cf. vindobonensis Schloenbach) dans le Vindobonien supérieur de Saubrigues (Landes) et histoire paléontologique des Sepiidae, B. Soc. géol. Fr., 5, 225-232, 1947.

Seilacher, A. and Chinzei, K.: "Remote biomineralisation II: Fill skeletons controlling bouyancy in shelled cephalopods", N. Jb. Geol. Pal. Abh., 190, 363-373, 1993.

Sprigg, R. C., Cochrane, G. W., and Solomon, M.: Penola sheet $1: 253,440$, Geological Atlas of South Australia, Geological Survey of South Australia, Adelaide, 1951.

Turco, E., Iaccarino, S. M., Foresi, L. M., Salvatorini, G., Riforgiato, F., and Verducci, M.: Revisiting the taxonomy of the in termediate stages in the Globigerinoides-Praeorbulina lineage, Stratigraphy, 8, 163-187, 2011.

Yancey, T. E., Garvie, C. N., and Wicksten, M.: The Middle Eocene Belosaepia ungula (Cephalopoda: Coleoidea) from Texas: structure, ontogeny and function, J. Paleontol., 84, 267-287, 2010.

Yoshida, M. A., Tsuneki, K., and Furuya, H.: Phylogeny of selected Sepiidae (Mollusca, Cephalopoda) based on 12S, 16S, and COI 
sequences, with comments on the taxonomic reliability of several morphological characters, Zool. Sci., 23, 341-351, 2006.

Ward, P. D. and Boletzky, S. V.: Shell implosion depth and implosion morphologies in three species of Sepia (Cephalopoda) from the Mediterranean Sea, J. Mar. Biol. Assoc. UK, 64, 955-966, 2009.
Weaver, P. G. and Ciampaglio, C. N.: A new genus of belosaepiid (Coleoidea) from the Castle Hayne Limestone (Eocene) of southeastern North Carolina, J. Paleontol., 77, 1103-1106, 2003.

White, M. R.: Subdivision of the Gambier Limestone, MESA Journal, 1, 35-39, 1996. 